Postgraduate Bosowa University Publishing (PBUP)
Indonesian Journal of Business and Management
e-ISSN: $2460-3767 \quad p$-ISSN: $2656-6885$
Pttps://postgraduate.universitasbosowa.ac.id/index.php/jbm

\title{
PENGARUH KONFLIK PERAN GANDA TERHADAP STRES KERJA PADA KARYAWAN WANITA DI PT.SOUTH SUCO MAKASSAR
}

\section{The Effect Of Multiple Role Conflict On Work Stress On Women Employees At PT. South Suco Makassar}

\author{
Arie Gunawan $\mathrm{HZ}^{1}$, Musawwir ${ }^{1}$, Rahmawati ${ }^{1}$ \\ ${ }^{1}$ Program Studi Psikologi Universitas Bosowa \\ Email: Arie.gunawan@universitasboswa.ac.id \\ Diterima: 05 Januari 2021/Disetujui: 02 Juni 2021
}

\begin{abstract}
ABSTRAK
Penelitian ini bertujuan untuk mengetahui pengaruh konflik peran ganda terhadap stres kerja pada karyawan wanita di PT. South Suco Makassar subjek penelitian ini adalah karyawan wanita di PT. South Suco Makassar sebanyak 100 orang karyawati. Teknik pengambilan sampel menggunakan non random secara purposive. Data penelitian dikumpulkan dengan skala konflik peran ganda dan skala stres kerja. Analisa data menggunakan regresi linear sederhana dengan bantuan Lisrel 87.0 dan Spss 20,0 for windows. Berdasarkan hasil analisa penelitian diperoleh Thitung > Ttabel $(4,141>3,392)$ dengan signifikansi lebih besar dari 0,05 yaitu 0,000, sehingga dapat disimpulkan bahwa Ho ditolak dan Ha diterima, yang berarti bahwa ada pengaruh konflik peran ganda terhadap stres kerja pada karyawan wanita di PT. South Suco Makassar. Hasil pengolahan data diperoleh nilai $\mathrm{R}=0,386 ; \mathrm{R}^{2}=0,149$ yang di tafsirkan bahwa variabel bebas $\mathrm{X}$ memiliki pengaruh kontribusi sebesar 0,149 atau 14,9\% terhadap variabel Y dan 85,1\% lainnya dipengaruhi Oleh variabel lain yang tidak menjadi fokus pada penelitian ini.
\end{abstract}

Kata Kunci: Stress Kerja, Peran Ganda, Wanita

\begin{abstract}
This study aims to determine the effect of multiple role conflict on work stress on female employees at PT. South Suco Makassar the subjects of this study are female employees at PT. South Suco Makassar as many as 100 employees. The sampling technique used non-random purposively. The research data were collected using multiple role conflict scale and work stress scale. Data analysis used simple linear regression with the help of Lisrel 87.0 and Spss 20.0 for windows. Based on the results of the research analysis, it was obtained that tcount> ttable (4.141> 3.392) with a significance greater than 0.05, namely 0.000, so it can be concluded that Ho is rejected and Ha is accepted, which means that there is an effect of multiple role conflict on work stress on female employees at PT. . South Suco Makassar. The results of data processing obtained the value of $R=0.386 ; R^{2}=0.149$ which is interpreted as the independent variable $X$ has a contribution effect of 0.149 or $14.9 \%$ to variable $Y$ and $85.1 \%$ is influenced by other variables that are not the focus of this study
\end{abstract}

Keywords: Work Of Stress, Double Role, Woman

\section{PENDAHULUAN}

Era globalisasi seperti saat ini, tenaga kerja wanita bukanlah hal asing yang sering didengar. Kesejajaran kedudukan antara pria dan wanita sudah tidak menjadi kendala bagi wanita untuk melakukan pekerjaan yang biasa dilakukan oleh pria seperti halnya mencari nafkah atau bekerja. Tak dapat disangkal lagi, kehadiran kaum wanita dalam dunia kerja besar manfaatnya dan perlu. Sebagai partner kaum pria, tidak hanya dirumah tapi juga dalam bekerja dengan menyalurkan potensi dan bakatbakat mereka. Kemajuan dan peningkatan kaum wanita yang sangat pesat di dunia kerja memang sudah bukan persoalan baru lagi (Anoraga, 2009). Data Badan Statistik Pusat Provinsi Sulawesi Selatan tahun 2016 angkatan kerja di Sulawesi Selatan pada Agustus 2016 berjumlah $3,881,003$ orang. Tenaga kerja yang tertinggi di sektor Industri pengolahan sebanyak 53 ribu orang dibandingkan sektor lapangan kerja lainnya (BPS Provinsi Sulawesi 
Selatan, 2016). Ini menandakan partisipasi tenaga kerja di sektor industri yang paling banyak diminati. Data Badan Statistik Pusat Kota Makassar pada indikator kesejahteraan rakyat kota Makassar tahun 2015 tingkat partisipasi angkatan kerja pada wanita di Kota Makassar tahun 2014 sebesar 42,25 persen (BPS Kota Makassar, 2015). Peningkatan angkatan kerja wanita cukup tinggi memberikan indikasi bahwa kesadaran wanita untuk aktif berpartisipasi dalam membangun ekonomi semakin besar. Keputusan untuk mengambil dua peran yang berbeda yaitu tugasnya sebagai ibu rumah tangga dan tanggung jawabnya sebagai karyawati keputusan yang dari dalam dirinya, karena keadaan terdesak demi membantu kebutuhan sehari-hari. Pekerjaan dan keluarga, dua hal yang umumnya tak bisa lepas dari keseharian karyawati dalam berpartisipasi di dunia industri pada era globalisasi seperti sekarang. Pembagian waktu terkadang tak semudah yang dibayangkan. Kedua-duanya ingin menjadi prioritas utama. Apabila kedua peran tidak berfungsi dengan baik pekerjaan jadi berantakan. Penelitian sebelumnya dilakukan oleh Wulandari dan Wibowo (2013) mengatakan bahwa perawat wanita RSUD Banyumas yang sudah menikah memiliki kesulitan dalam membagi waktu untuk melaksanakan tugasnya sebagai ibu, merasa lelah dengan pekerjaan rumah tidak dapat berkonsentrasi dengan baik ketika memiliki permasalahan dengan keluarga dan tidak memiliki semangat bekerja ketika tidak mampu menjalankan perannya sebagai ibu karena terhambat pekerjaannya. Kesulitan yang dirasa perawat wanita tersebut memunculkan perasaan khawatir, cemas, bingung, sukar berkonsentrasi, mudah marah, malas, pusing, cepat merasa lelah, tidak bersemangat, tidak menunda pekerjaan. Konflik peran ganda yang muncul pada perawat ini dapat memicu stres kerja. Salah satu perusahaan yang dominan mempekerjakan tenaga kerja wanita adalah PT. South Suco Makassar. HRD di perusahaan tersebut menyatakan jumlah keseluruhan tenaga kerja di perusahaan ini pada bulan November 2016 adalah 223 orang dengan berstatus karyawan tetap dan jumlah tenaga kerja wanita yang telah berkeluarga dan memiliki anak sebanyak 120 orang, tetapi pada bulan Mei 2017 jumlah tenaga kerja wanita yang telah berkeluarga dan memiliki anak sebanyak 100 orang. Perusahan ini bergerak di bidang ekspor udang beku dengan negara tujuan yang paling besar adalah negara jepang. Tenaga kerja yang lebih dominan wanita yang dituntut memiliki keterampilan, ketelitian, kompeten dan tanggung jawab yang tingg terhadap pekerjaannya terutama karyawan wanita di bagian produksi. Profesi sebagai karyawan dituntut mencapai target dalam pekerjaannya, karyawan pun bekerja selalu dalam pengawasan. Tak dapat dipungkiri, tanggung jawab yang seharusnya dapat berfungsi dengan baik terkadang tidak difungsikan dengan baik. Hal ini disebabkan karena karyawan wanita tidak bersemangat, kondisi fisik yang tidak bersahabat, ruang geraknya terbatas, kurang berkonsentrasi, banyak pikiran sehingga karyawan wanita rentan stres. Hal ini perlu diperhatikan karena karyawan wanita yang telah berkeluarga memiliki peran dan tanggung jawab yang ganda, yakni sebagai ibu rumah tangga dan wanita yang bekerja. Kedua peran ini sama-sama membutuhkan waktu dan perhatian penuh dalam pemenuhannya. Kondisi stres pun timbul akibat peran yang dijalani karyawan bertentangan. Kondisi cemas, khawatir dan sulitnya berkonsentrasi menimbulkan stres pada karyawan yang memiliki dua peran antara pekerjaan dan keluarga. Penelitian sebelumnya yang dilakukan oleh Sianturi dan Zulkarnain (2013) menyatakan bahwa dibutuhkan usaha yang lebih dari individu dalam mengatur tuntutan perannya agar konflik peran ganda dapat minimalisir. Ketika terjadi ketidakseimbangan dalam memenuhi tuntutan peran keluarga dan pekerjaannya, maka akan muncul work-family conflict. Terkadang mereka merasa kasihan terhadap anak-anaknya, yang telah mereka tinggalkan demi membantu memenuhi kebutuhan sehari-hari dan tanggung jawab sebagai karyawati. Greenhaus dan Beutell (Laksmi \& Hadi, 2012), yang menyatakan konflik peran ganda sebagai suatu bentuk konflik peran dalam diri seseorang yang muncul karena adanya tekanan peran dari pekerjaan yang bertentangan dengan tekanan peran dari keluarga. Konflik peran ganda bisa terjadi akibat lamanya jam kerja seseorang, sehingga waktu bersama keluarga menjadi kurang. Individu harus menjalankan dua peran secara bersamaan yakni dalam pekerjaan dan dalam keluarga. Fenomena-fenomena yang terjadi pada wanita yang bekerja sebagai karyawati khususnya dibagian produksi, dapat diketahui bahwa konflik-konflik yang terjadi pada karyawan wanita dalam bekerja terutama konflik peran ganda yang dimilikinya. Apabila konflik peran ganda yang dimiliki karyawan wanita tidak dapat diatasi akan berpengaruh terhadap kondisi psikologisnya, akan menimbulkan stres pada pekerjaannya, sebab salah satu faktor yang dapat mempengaruhi kondisi stres pada pekerjaan adalah keluarga.

\section{METODE PENELITIAN}

Penelitian ini merupakan penelitian kuantatif yang menggunakan metode analisis regresi linear sederhana. Subjek penelitian yang digunakan dalam penelitian ini berjumlah 100 orang karyawan wanita berusia 25-50 tahun yang sudah berkeluarga di PT.South Socu Makassar dengan status bersuami (bukan janda) yang kesehariannya tinggal serumah bukan tinggal bersama keluarga besar dan memiliki kaarakteristik suami bekerja, memiliki anak minimal 1 orang berusia 0-12 tahun, dan memenuhi target yang telah ditetapkan oleh perusahaan. Dalam pengambilan data, instrument yang digunakan yaitu skala stress kerja dan skala konflik peran ganda yang mana skala stress kerja berdasarkan gejala-gejala yang dikemukakan oleh Beehr dan Newman (Luthans, 2005) yang terdiri 24 item. Sedangkan untuk skala konflik peran ganda berdasarkan dimensi-dimensi yang dikemukakan oleh Greenhaus dan Beutell (1985) yang terdiri dari 30 item.

\section{HASIL DAN PEMBAHASAN}


Dari penelitian diperoleh sebagai berikut : Tingkat stres kerja di PT. South Suco Makassar dalam kategori sedang dengan presentase $45 \%$. Hal ini menunjukkan bahwa sebagian karyawati di PT. South Socu Makassarcenderungmampu mengatasi hambatanhambatan dalam pekerjaannya yang dapat menimbulkan stres dalam bekerja. Tingkat Konflik Peran Ganda di PT. South Suco Makassar dalam kategori sedang dengan presentasen $51 \%$. Hal ini menunjukkan bahwa karyawati di PT. South Suco Makassar cenderung mampu meminimalisir waktunya antara peran dalam pekerjaan dan peran dalam keluarga. Berdasarkan hasil analisa data nilai korelasi sebesar 0,386 dengan taraf signifikan dari konflik peran ganda sebesar 0,000 (dimana 0,000 > 0,05), ditolak dan Ha diterima. Hal menunjukkan bahwa ada pengaruh antara konflik peran ganda terhadap stres kerja pada PT. South Suco Makassar sehingga hipotesis yang diajukan dapat diterima.

\section{KESIMPULAN DAN SARAN}

Kesimpulan dari penelitian ini tingkat strees tergolong sedang berada pada tingkat $45 \%$. Hal ini menunjukkan bahwa karyawati di PT. South Suco Makassar cenderung mampu meminimalisir waktunya antara peran dalam pekerjaan dan peran dalam keluarga. Berdasarkan hasil analisa data nilai korelasi sebesar 0,386 dengan taraf signifikan dari konflik peran ganda sebesar 0,000 (dimana $0,000>0,05$ ), ditolak dan Ha diterima. Hal menunjukkan bahwa ada pengaruh antara konflik peran ganda terhadap stres kerja pada PT. South Suco Makassar sehingga hipotesis yang diajukan dapat diterima.

\section{DAFTAR PUSTAKA}

Anoraga, P., (2009). Psikologi Kerja. Jakarta: PT. Rineka Cipta.

Badan Pusat Statistik. (2015). Indikator Kesejahteraan Rakyat Kota Makassar (4103.7371). Makassar: BPS.

Badan Pusat Statistik. (2016). Keadaan

Ketenagakerjaan Sulawesi Selatan Agustus 2016. Provinsi Sulawesi Selatan: BPS.

Beutell, N.J., \& Greenhauss, J.H. (1985). Sources of Conflict Between Work and Family Roles. Academy of Management Review, 10,76-88.

Laksmi, N.A., \& Cholichul, A. (2012). Hubungan antara Konflik Peran Ganda (Work Family Conflict) dengan Kepuasan Kerja pada Karyawati Bagian Produksi PT. X. Jurnal Psikologi Industri dan Organisasi, 1, 24-130.

Luthans, F., (2005). Organization Behavior. New York: Mc Graw-Hill.

Sianturi, M., \& Zulkarnain. (2013). Analisis Work Family Conflict Terhadap Kesejahteraan Psikologis Pekerja. Jurnal Sains dan Praktik Psikologi, 1, 207-215.
Sutarjo, P. S. D. A., Cahyono, C., \& Saleh, H. (2021). Pengaruh Stres Kerja, Organizational Citizenship Behavior Dan Komitmen Organisasi Terhadap Kinerja Karyawan Pt Japfa Comfeed Indonesia Tbk. Unit Corn Dryer Sidrap. Indonesian Journal of Business and Management, 2(2), 63-70.

Wulandari, D., \& Wibowo, U. (2013). Hubungan antara Konflik Peran Ganda dengan Stres Kerja pada Perawat Wanita yang Sudah Menikah di RSUD Banyumas. Psychoidea, 1, 67-78. . 